\title{
Hyvin menee, jos siltä näyttää
}

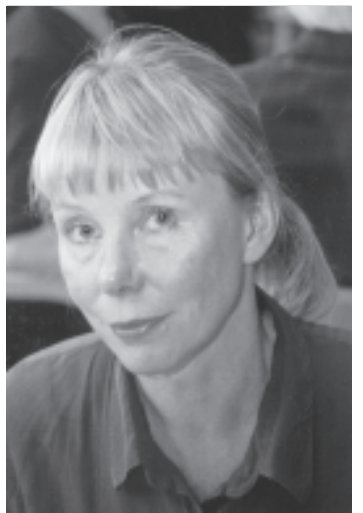

Kollega Jukka Tuomisto jätti alkusyksystä jäähyväiset pitkään kestäneestä aikuiskasvatuksen tutkijan ja opettajan virastaan. Jukan kokemus näytti olevan se, että suomalainen aikuiskasvatus on tieteellisenä opinja koulutusalana laajentunut, vahvistunut ja kansainvälistynyt.

Aikuiskasvatus on toki pääaineena seitsemässä yliopistossa, virkoja ja opinnäytetyöntekijöitä on kohtuullisesti, mutta ATS:n johtokuntaan välittyvät kuulumiset herättävät myös huolta sen nykytilasta ja varsinkin tulevaisuudesta.

Marraskuun alussa Aikuiskasvatuksen eurooppalainen tutkimusseura (ESREA, esrea.org) piti johtokunnan kokouksen ja seuran uusi aikuiskasvatuksen ammattilaisuutta tarkasteleva tutkimusverkosto (ReNAdET) ensimmäisen tapaamisensa Thessalonikissa. ESREA on uuden johtokunnan ja sihteeristön myötä jo pari vuotta vilkastunut ja osallistuminen eri puolilta Eurooppaa tasapainottunut. Seura julkaisee omaa kirjasarjaa ja on käynnistämässä Journal of Research on Education and Learning of Adults -lehteä (RELA, rela.ep.liu.se) open access-periaatteella. Itse olen viimeksi osallistunut Life history and biographical research on adult education-, History of Adult Education and Training- sekä Adult Educators, Trainers and their Professional Development-verkostojen tapaamisiin ja järjestelyihin. Viimeksi mainitun aloitustilaisuudesta tulikin yli 200 osallistujan konferenssi. EU:ssa ja jäsenvaltioissa omaksuttu elinikäisen oppimisen politiikka ja aikuiskoulutuksen radikaali lisääntyminen ovat tehneet aiempaa näkyvämmäksi aikuiskasvatustyön ja -tekijät, joten paine aiheen tutkimukseen myös kasvaa. Osallistujien lukuisuus johtui myös Itä-Euroopan maiden tutkijoiden aktiivisuudesta. Siitä on kiittäminen verkoston vetäjän Giorgios Zarifiksen tiedotustyötä ja apua matka- ja majoitusjärjestelyissä. Uusina ovat käynnistymässä myös Policy Analysis- ja Education and Learning of Older Adults-tutkimusverkostot. Verkostojen toimintaa voi seurata ESRE-
An kotisivuilta. ATS:n jäsenet voivat osallistua tapahtumiin ja saada julkaisuja jäsenhintaan ja jatko-opiskelijat voivat anoa tukea kuluihin.

Keskustelut aikuiskasvatustutkimuksen luonteesta ja tarkoituksista ovat myös ESREAssa kiihtyneet. Kyse lienee sukupolvenvaihdoksesta ja jämähtämään päässeistä koulukunta- ja arvovaltaasetelmista, mutta osaksi myös uusista aiheista, osallistujista ja toimintatavoista. Tässä tilanteessa huolettaa suomalaisten tutkijoiden laiskuus tai välinpitämättömyys ESREAn tutkimusverkostoissa ja toiminnassa. Jos aktiivisuus kanavoituu muualle - yleisseuroihin, oppimisen ja opetuksen tutkimusseuroihin -, mistä tässä on kyse? Onko elinikäisen oppimisen, työssä oppimisen, ohjauksen ym. tematiikka todella läpäissyt kaiken kasvatustieteellisen tutkimuksen vai ohjaako yliopistojen profiloitumis- ja virtaviivaistamispolitiikka tutkijat entistä strategisempiin liittoutumiin ja keskinäiseen kilpailuun? Ehkä tieteenalan ja yliopistollisen koulutuksen laajentuminen kasvatustieteiden laitoksilla ei oikeasti ole tarkoittanutkaan aikuiskasvatuksen teoreettista ja tutkimuksellista vahvistumista, vaan lisää sijoittumismahdollisuuksia muille kuin opettajankoulutukseen suuntautuneille tutkijoille. Kuinka monella laitoksella virassa toimijat ja opinto-ohjelmat todella enää suuntautuvat aikuiskasvatukseen?

aradoksaalisesti aikuiskoulutus ja elinikäinen oppiminen ovat kansallisessa ja ylikansallisessa koulutuspolitiikassa nousseet entistä keskeisempään asemaan. Eurooppalainen elinikäisen oppimisen pätevyyksien viitekehys ja siihen liittyvä laadunvarmistuksen viitekehys ovat tekeillä ja elinikäinen oppiminen on säädetty lähes kaikkien koulutusmuotojen ja -asteiden tehtäviin. Nykyisellään aikuiskasvatustiede ei kuitenkaan pysty kilpailemaan yhteiskuntatieteiden tai yleisen kasvatustieteen kanssa suurista kansallisista rahoituksista. Projekteilla hallinnan politiikan oloissa julkishallinnon rahoitus on tilapäistä ja pirstaleista ja markkinaperusteinen rahoitus vähäistä eivätkä kumpikaan tähtää tieteenalan käsitteelliseen, teoreettiseen ja metodologiseen kehittämiseen. Pitkäjänteinen teoriankehittely edellyttää toki tutkimusta, jonka laboratorio on aikuiskasvatustodellisuus. 
Aina voi toivoa asioiden muuttuvan, mutta sitä odotellessa olisi syytä miettiä, miten jo olemassa olevat resurssit voisi käyttää rakentavammin. Yliopistoissa on nyt meneillään ankara isojen yksiköiden ja strategisten aineyhdistelmien rakentaminen. Onko ajatus kansallisesta yhteistyöstä aikuiskasvatuksen tutkimuksessa ja tieteellisessä koulutuksessa mahdoton? Merkittävimmän osan vapaan sivistystyön, ammatillisen ja opillisen aikuiskasvatuksen ja henkilöstönkehittämisen tutkimusta tekevät jatkossakin virassa toimivat ja opinnäytetyön tekijät. He voisivat paremmin koor- dinoidussa tilanteessa rakentaa teorian, käytännön ja politiikan välille kriittistä keskustelufoorumia, jolla myös ylikansallisia muutoksia voitaisiin tarkastella kansallisessa kehyksessä. Tähän solidaarisempienkaan tutkijoiden omat voimat tuskin riittävät: tutkimuksen ja tieteellisen koulutuksen tarpeiden pitäisi koordinoidummin välittyä myös aikuiskasvatuksen toimintakentiltä ja alan ammattilaisilta.

\section{Anja Heikkinen}

